\title{
Value-Based Intermediation: An Analysis from The Perspective of Shariah And Its Objectives
}

\author{
Rusni Binti Hassan ${ }^{(1)}$, Fatimah Mohamad Nor(2)
}

\begin{abstract}
Despite considerable growth across the globe, including Malaysia, Islamic banking and finance has witnessed substantial criticism over the lack of social concern in its economic activities, which is one of the most significant elements of the objectives of Shariah. Currently, Bank Negara Malaysia has taken a new initiative by introducing Value-Based Intermediation (VBI). It plays a crucial role in delivering the objectives of Shariah through various strategies. The aim of this paper, hence, is to explore the Shariah principles that have been embedded in VBI. It also aims to discuss the objectives of Shariah in VBI. This paper is qualitative, descriptive, and exploratory. It employs document analysis and library research whereby the data is mainly derived from both primary and secondary sources. This paper is confined to only a conceptual discussion on the implementation of Shari ah and its objectives in VBI. The findings indicate that there are at least five Shariah principles that have been embedded in VBI. Furthermore, the general Shariah objective of having VBI is to deliver justice, establish values, and enhance social responsibility. However, the specific Shariah objective of VBI is to achieve preservation of wealth through various tools and mechanisms. Finally, this paper contributes to the body of knowledge by giving insights on the implementation of the Shariah and its objectives in VBI, and it could be used as a reference in developing a sound Islamic ethical foundation for future Islamic financial institutions that is lacking in Islamic finance literature.
\end{abstract}

Keywords: Value-Based Intermediation (VBI), Shariah, Maqāsid al-Sharīah.

الوساطة المبنية على القيمة: دراسة تحليلية من منظور الشريعة ومقاصدها ملخص البحث

وعلى الرغم من نمو ملحوظ في الصيرفة والمالية الإسلامية في أنحاء العالم بما في ذلك ماليزيا، فإن هناك انتقادات حول قلة الاهتمام بالمجتمع في نشاطاتا الاقتصادية، وهو من أهم عناصر مقاصد الشريعة. ويبادر البنك المركزي الماليزي حاليَّا إلى اتخاذ خطة لتعريف الوساطة المبنية على القيمة -Value) Based Intermediations) (VBI) مبادئ الشريعة المتضمنة في VBI، كما يهدف إلى إجراء مناقشة حول مقاصد الشريعة في VBI. ويعتمد البحث على المنهج الكيفي، والوصفي، والاستطلاعي، باستخدام طريقة التحليل الوثائقي والبحث المكتبي لاستباط البيانات من المصادر الرئيسية والمصادر الثانوية. ويتمحور البحث في حدود نقاش علمي حول مفاهيم الوساطة المبنية على القيمة (Value-Based Intermediations) (VBI) من منظور الشريعة ومقاصدها. وتشير نتائج

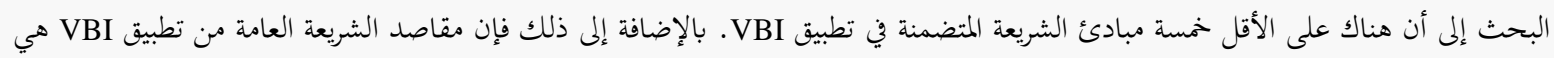

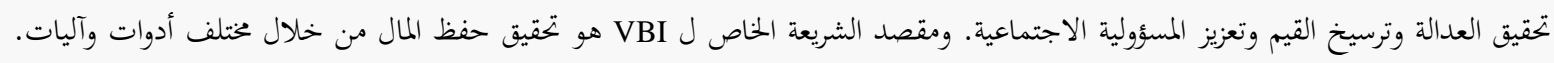

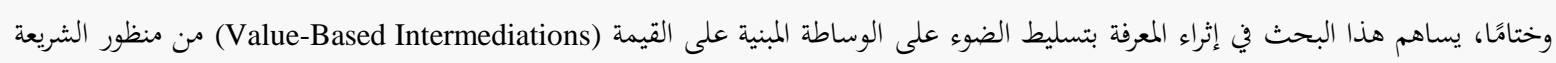

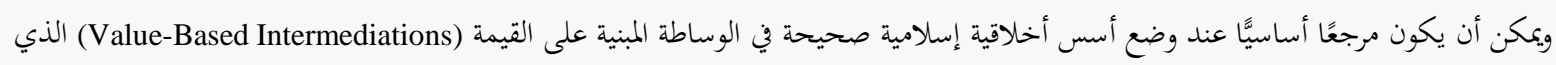
ما زلنا نفتقر إليه حتى الآن في مجال الدراسات المتعلقة بالتمويل الإسلامي. كلمات مفتاحية: الوساطة المبنية على القيمة، الشريعة، مقاصد الشريعة.

(1) Professor, Institute of Islamic Banking and Finance, International Islamic University Malaysia. hrusni@iium.edu.my

(2) PhD Student, Institute of Islamic Banking and Finance, International Islamic University Malaysia. fmnzahraa88@gmail.com

\section{Contents}

1. Introduction

2. The Concept of Value-Based Intermediation

2.1 The Underpinning Thrusts of VBI

3. Shariah Principles of Value-Based Intermediations

3.1 The Concept of Shariah

3.2 Shariah Principles of VBI

4. Value-Based Intermediation from Maqasidic Perspective

4.1 The Meaning of Maqasid Shariah

4.2 Categorizations of Maqasid Shariah
4.3 General Shariah Objectives of VBI

86

4.4 Specific Shariah Objectives of VBI

4.5 VBI and The Achievement of Public Interest (Maslahah)

5. Conclusion

References

\section{Introduction}

The past thirty years have seen rapid advances in Islamic banking and finance, and it can be considered as a part of the global financial system, particularly in 
Malaysia. The world has recognized Malaysia as a leading country that has successfully developed its Islamic banking model. Shariah-compliant financial solutions offered by the Islamic banking industry in Malaysia (including development of financial institutions) continued to support the diverse needs of the economy in 2017. According to Bank Negara Malaysia (BNM), Islamic financing grew by $9.4 \%$ or RM605.5 billion (2016: 11.8\%) during the year. Also, Islamic financing of businesses sustained its positive growth of $7.8 \%$ (2016: $12.2 \%$ ) and was channelled mainly to the business services, finance, insurance, and manufacturing sectors. Business financing was driven by small and medium enterprises (SMEs), which grew by $12.5 \%$ (2016: $13.3 \%$ ), amid the more moderate growth in conventional lending to SMEs (3.1\%). Islamic home financing also continued to exhibit a strong growth of $17.5 \%$ (2016: $16.3 \%$, conventional loans $6.0 \%$ ), reflecting the growing acceptance of Shariah-compliant home financing solutions (Bank Negara Malaysia, 2017).

Despite the great success stories of the growth of Islamic banking institutions (IBIs), they have received a lot of criticism due to their inactive participation in contributing to societal well-being, even though this actually is included in one of the Shariah objectives of IBIs. In this case, Asutay (2015) indicated in his study that there was a lack of achievement of Maqāṣid al-Sharī'ah in the performance of Islamic banks as the overall industry focuses mainly on self, faith, rights, and stakeholding, rather than wealth preservation. He also adds that there is minimal contribution from Islamic Banking and Finance (IBF) within the social entity, intellect, posterity, and ecology. Moreover, Abdullah (2017) reveals that the recent statistics on the development of the IBF industry in Malaysia with special reference to the market share of Islamic banks in Malaysia expanded from $7.1 \%$ in 2010 to $28 \%$ in 2016 . However, there was a decline in its annual growth rate from $24.2 \%$ in 2011 to $8.2 \%$ in 2016 . This decline indicates that industry stakeholders, especially the regulators and the industry players, have to build up new strategies and discover new opportunities. They must also find out ways to strengthen the necessary foundation of Islamic finance by not only focusing on Shariah-compliant matters on their products and services but also by unleashing the potential of Islamic finance. This is a system that attempts to realize Islamic values by promoting socio-economic justice, development, sustainability, and economic growth that stems from Maqāșid al-Sharī‘ah (objectives of Shariah).

Bank Negara Malaysia has officially introduced Value-Based Intermediation (VBI) as a new initiative for IBIs to be more impactful. This is not only for economic growth but also to allow them to have more participation in societal well-being as part of the intended outcomes of Shariah that help to maintain IBF's raison d'etre. The question is, can this new initiative help to improve the greater achievement of Maqāṣid al-Sharī'ah in IBIs? Therefore, the aim of this study to discuss the Shariah point of view on the implementation of VBI in Malaysian IBIs while exploring the Maqāṣsid al-Sharī‘ah in VBI.

\section{The Concept of Value-Based Intermediation}

Value-Based Intermediation (VBI) is defined as "an intermediation function that aims to deliver the intended outcomes of Shariah through practices, conduct, and offerings that generate positive and sustainable impact to the economy, community and environment, consistent with the shareholders' sustainable returns and long-term interests" (BNM Strategy paper, 2017).

There are three fundamental mechanisms of VBI that are believed to give change and are more impactful towards bank offerings and practices:

1. Offerings and market segments - the introduction of innovative products and services to create a greater impact on the existing market segment as well as an impact-driven mindset that drive IBIs to focus on high-impact areas such as new growth areas and underserved segments.

2. Practices - improvement in existing banking practices and adoption of techniques such as offtake agreement or supply chain finance. It enables industry players to manage the risks arising from serving highimpact segments.

3. Collaboration - enhanced collaboration with strategic partners and stakeholders (beyond the 
financial community) to leverage on specific skills and infrastructure that are critical but not owned by the IBIs.

In line with the establishment of VBI, the BNM has also developed VBI scorecards to measure the adoption of this initiative in IBIs. The scorecards will be utilized as an assessment tool and will also be publicly disclosed to allow stakeholders to compare the performance of IBIs (BNM Strategy Paper, 2017).

\subsection{The Underpinning Thrusts of VBI:}

According to BNM, IBIs must ensure that their strategy manifests the four underpinning VBI principles (BNM Strategy Paper, 2017):

1. Entrepreneurial mindset - the focus of this area is premised on greater involvement in facilitating entrepreneurial activities through holistic offerings by IBIs, which includes financing and proactive support, i.e. advisory, market infrastructure and business network.

2. Community empowerment - it is aimed to empower communities through the provision of financial solutions that create a positive impact.

3. Good self-governance - this thrust concerns inculcating organisational discipline (selfrestraint) and ensuring the meaningful participation of all stakeholders in the governance framework.

4. Best conduct - the focus of these principles is to adopt practices that improve IBIs' offerings, processes, and treatments toward their stakeholders (including IBIs' customers and employees).

\section{Shariah Principles of Value-Based Intermediations}

\subsection{The Concept of Shariah:}

Shariah is defined literally as a 'source of water' or 'path to a watering place' (ISRA, 2011). Shariah scholars have different views in defining the meaning of Shariah. Some scholars defined Shariah as rulings related to the laws and beliefs that are revealed through the Prophet (PBUH) while others define Shariah as the commands of Allah (SWT) (ISRA, 2011). There are also scholars who define Shariah in a wider perspective by considering it "as a system of life that encompasses all aspects of the belief system, the system of ethics and morals and the rules that govern the relationship between men and God (Ibadah) and between man and Man (muamalat)" (ISRA, 2011). The third definition gives a comprehensive view and the scope of Shariah.

\subsection{Shariah Principles of VBI:}

Shariah principles in VBI are identified through its underpinning thrusts, which represent the core elements of VBI, and they are as follows:

1. Principles of Islamic business:

Islam encourages people to work and it is considered an ibadah if it is done for the sake of seeking the blessings of Allah (SWT). It also includes business activities that enable people to earn income from halal sources. Apart from that, Islam also stresses the importance of referring to the Islamic financial transaction that guides human business activities (Lahsasna, 2013). Prophet (PBUH) says, "Nine out of ten sources of income come from business activities." (Hadīth narrated by al-Tirmidhi).

In line with the aforesaid hadith, the aim 'Entrepreneurial Mindset' in VBI's thrust is to improve the involvement of IBIs in facilitating entrepreneurial activities through holistic offerings, which include financing and proactive support through, for example, providing advisory and market infrastructure, and business networks (BNM Strategy Paper, 2017). Furthermore, seizing the opportunity to offer holistic offerings to entrepreneurial activities will ultimately increase IBIs' innovation through the development of new products, tools and business models to support businesses and entrepreneurs. Thus, VBI aims to develop a supportive and proactive environment for facilitating entrepreneurial activities as well as to uphold the spirit of entrepreneurship as promoted in Islam (BNM Strategy Paper, 2017).

2. Principle of Social obligation (Farḍ Kifāyah):

In Islamic teachings, every Muslim is expected to embrace the sense of social responsibility towards the community. In the Islamic economic system, this principle allows people to earn their living in a fair and 
profitable way without exploitation of others so that the entire society may benefit from it (Lewis, 2006).

This principle has been embedded in the thrust of 'Community Empowerment' whereby it is a thrust that is created to empower society through the establishment of financial solutions that create a positive impact among them. As a result, an IBI can play a significant role in creating socially sustainable economic impacts for the communities with a balanced consideration between commercial and social aspects. That can be achieved through the development, funding, and implementation of effective solutions for issues faced by the communities, which aim to create a positive impact on the communities and new business opportunities for IBIs. An example includes the integration of waqf and sadaqah within Islamic financial transactions (BNM Strategy Paper, 2017).

3. Principle of righteousness (Ihsān):

In the Quran, the concept of Ihsan is explained as a complementary to justice, Allah (SWT) says in the Quran:

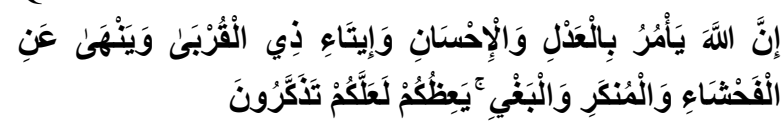

"Indeed, Allah orders justice and good conduct and giving to relatives and forbids immorality and bad conduct and oppression. He admonishes you that perhaps you will be reminded." (AlQur'ān, 16:19)

Islam is a religion, which actively promotes the sense of benevolence (ihsān). Although the word justice (' $a d l$ ) and righteousness are concurrently used in the above verse, they have a different meaning in which the word justice is a legal concept while ihsān refers to the moral concept. In this regard, Islam encourages the Muslim to go a step further beyond the framework of justice, in the pursuit of excellence and perfection in all deeds and actions (Asutay, 2015). The Hadith of Gabriel in which Prophet Muhammad (PBUH) states "Ihsan is to worship God as though you see Him, and if you cannot achieve this state of devotion then you must consider that He is looking at you" (Hadith Narrated by al-Bukhārī, 1980: Vol. 1, Book 2; Hadith No. 47) is one of the manifestations of the pursuance of excellence and perfection in life (Asutay, 2015).

The concept of Ihsan is manifested in VBI through the thrust of 'Good Self-governance' whereby it refers to "inculcating organizational discipline (self- restraint) and ensuring meaningful participation of all stakeholders in the governance framework" (BNM Strategy Paper, 2017). There are two main components of good self-governance: inclusive governance and self-governance. A manifestation of the concept of Ihsān can be seen directly in self-governance in which the culture of self-discipline is embedded within the operations and practices of IBIs. As a result, greater accountability and integrity of the IBIs can be achieved in line with the concept of ihsān, which is profoundly important to bring goodness to the community and in preventing harm (BNM Strategy Paper, 2017).

4. Principles of consultation (Istishārah):

Istishärah is an Arabic terminology that is closely related to the concept of shura. This terminology is rooted in the Quran as Allah SWT says:

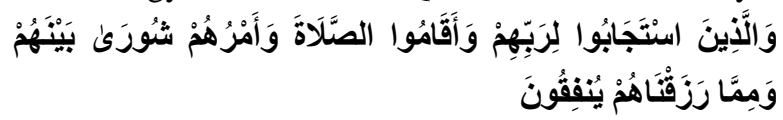

"And those who have responded to their lord and established prayer and whose affair is (determined by) consultation among themselves, and from what We have provided them, they spend." (AlQur'ān, 42:38)

The concept of shura refers to the notion to be faithful in mutual consultation and tolerance and to rely on Allah (SWT). It also comprises the core aspect of governance from an Islamic perspective. As Muslims, they must ensure that their conduct of life is based on mutual consultation between those who are entitled the voice and responsibility in, for example, affairs of business, as between the partners or interested parties, and state affairs as between rulers and the ruled (Lewis, 2006). Furthermore, as the Quran has mentioned that any decision involving more than one party requires access and consultation based on the principles of shura, Islam encourages the participants to work together freely and frankly when arriving at decisions. The institution of the shuratic decision-making process explains how decision-making in business and other activities can meet Islamic moral values (Lewis, 2006).

This principle is manifested through the thrust of 'good self-governance' and more specifically in inclusive governance. Inclusive governance refers to any decision made by an IBI that impacts not only on its shareholders but also the extended stakeholders, including the customers and investors. This thrust explicates that IBIs are required to engage their 
stakeholders in the key decision-making process proactively. Such holistic consultation provides IBIs with better perspectives, insights, and expectations that will determine or influence the outcome of their business plans (BNM Strategy Paper, 2017).

5. Principles for contracting parties:

Shariah provides a set of rules and principles about the contracting parties as a guidance for IBIs in their business activities. This is to ensure that the Muslim community in particular are able to obtain endto-end Shariah-compliant financial services from IBIs (Laldin \& Furqani, 2013). Those rules and principles are set to protect the contractual relationship in contractual terms in order to avoid continuous disputes due to unfair and oppressive contractual terms (Mahinar \& Bakar, 2017). In this case, BNM provides some indicators to enable the best conduct of IBIs through having a customer satisfaction index and statistics on the number of complaints by consumers, and this enhances the transparency level and encourages the development of codes of conduct (Mahinar \& Bakar, 2017).

\section{Value-Based Intermediation from Maqasidic Perspective}

It is believed that VBI is an attempt to promote a more holistic view of Shariah that is beyond Shariahcompliance in the business activities of IBIs. According to BNM (2017), wealth preservation forms the core of the Shariah objectives in financial transactions of IBIs. However, VBI's approach for wealth preservation goes beyond its literal meaning since it includes encouragement to generate, accumulate, and distribute the wealth in a just and fair manner (BNM Strategy Paper, 2017). This means that VBI has come to serve IBIs as a great place to contribute to social needs. It also emphasizes on developing ethical values for IBIs within the framework of Maqāșid al-Sharī‘ $a h$.

As stated by Laldin and Furqani (2013), Maqāșid al-Sharī'ah is a part of a system of life, which provides the basis for the construction of a comprehensive Islamic ethical system within IBIs. They further expounded that the practices of Shariahcompliance in IBIs should no longer be restricted to only fulfilling the legal aspects of Shariah (rules and ahkam) but also must be reconstructed with a more value-laden system inspired by Maqāșid al-Sharī'ah for the greater achievement of goodness for the entire humanity (Laldin \& Furqani, 2013).

Thus, the forthcoming section attempts to discuss and analyse the concept of VBI according to three main aspects of Maqāșid al-Sharī'ah, namely 1) general objectives of Shariah 2) specific objectives of Shariah and 3) the achievement towards Maslahah.

\subsection{The Meaning of Maqāṣid al-Sharī'ah:}

The word 'Maqāsid' is originated from the Arabic word 'maqsad' that means 'objectives'. Meanwhile, the term Maqāsid al-Sharī'ah is referred to as the objectives of Shariah. It is interesting to note that Shariah scholars have been contributing their works to develop the theory of Maqāșid al-Sharī'ah. Primarily, its purpose is to achieve benefits for all human beings. For example, Al-Ghazālī explains the meaning of Maqasid as follows:

"The very objective of the Shariah is to promote the
well-being of the people, which lies in safeguarding
their faith (din), their lives (nafs), their intellect (aql),
their posterity (nasl), and their wealth (mal).
Whatever ensures the safeguarding of these five
serves the public interest and is desirable, and
whatever hurts them is against public interest, and its
removal is desirable" (Al-Ghazāli, 1973, pp. 139-
140).

Al-Ghazālī’s definition of Maqāṣid al-Sharī‘ah emphasizes on five important aspects of the preservation of human life. However, Al-Ghazālī did not provide a comprehensive definition of Maqāṣid as a holistic value system as he mainly focused on the preservation of five things.

Meanwhile, Ibn 'Āshūr defined Maqāṣid in a broader and universal sense as he opined that:

\footnotetext{
"The overall objective (maqsad amm) of Islamic legislation is to preserve the social order of the community and ensure its healthy progress by promoting the well-being and virtue (salah) of the human being. The salah of the human being consists of the soundness of their intellects and the righteousness of their deeds, as well as the goodness of the things of the world in which they live that are put at their disposal' (Ibn 'Āshūr, 2006, p.87)
}

Furthermore, 'Allāl al-Fāsī defined Maqāṣsid alSharī'ah as the highest goal of Shariah which rests upon the ideas of compassion and direction and tries to 
set up equity, wipe out bias and mitigate hardship (Dusuki \& Bouheraoua, 2011). He asserted:

\begin{abstract}
"The overall objective of Islamic Law is to populate and civilize the earth and preserve the order of peaceful coexistence therein; to ensure the earth's ongoing well-being and usefulness through the piety of those who have been placed there as God's vicegerents; to ensure that people conduct themselves justly, with moral probity and with integrity in thought and action, and the need of reform on earth, that they tap its resources and plan for the good of all" ('Allāl al-Fāsī, 2014, p.3).
\end{abstract}

\subsection{Categorizations of Maqāṣid al-Sharī'ah:}

Dusuki and Bouheraoua (2014) further elaborate that Shariah scholars have categorized Maqāșid al-Sharī ${ }^{`} a h$ into two categories: general objectives (Maqāṣid 'Āmmah) and specific objectives (Maqāṣid Khāṣsah). General objectives may be referred to as what is beneficial and useful for the whole or most of the community; it is not much concerned about individuals except to the extent that they are its members (Ibn 'Āshūr, 2006). To some level, it is pertinent that the general objectives can be regarded as 'Maslahah' as indicated by Al-Shātibī. Additionally, Mașlahah can be referred to as a term as the 'consideration of public interest'. It mainly means the "utmost righteousness and goodness"' (Ibn 'Āshūr, 2006, p.96).

Ibn 'Āshūr also concluded that the term Mașlahah consists of two interests: public interest and private interest. As such, Mașlahah is divided into three categories according to their level of priority:

\section{The Indispensable (Darüriyyah)}

The first category aims to realize the essential need for the whole community collectively and individually. It means that if a defect happened to be in this category, the community will not function properly. In other words, this deficiency will lead to the mass destruction of the whole society. This category of mașlahah comprises safeguarding five things for the benefit of all human beings. They are the preservation of religion (hifz al-din), preservation of life (hifz al-nafs), preservation of intellect (hifz al-'aql), preservation of wealth (hifz al-māl), and preservation of lineage (hifz al-nasb) as explained by Al-Ghazālī, Al-Qarāfī and AlShātibī (Ibn 'Āshūr, 2006).

\section{The Complementary (Häjiyyah)}

This comprises the need of society to obtain their interests to function accordingly. This means if this category was ignored or overlooked, human beings would face difficulties and hardships in continuing their lives. However, this will not lead to mass destruction (Ibn 'Āshūr, 2006).

\section{The Embellishments (Taḥsiniyyah)}

This interest aims to find perfection in social conditions or order, which subsequently leads to tranquility in life. The focus of this category is on building the good manners and ethics of all human beings, such as encouraging the giving of voluntary charity (Ibn 'Ashūr, 2006).

Meanwhile, the specific objectives of Shariah refer to anything that benefits the individuals. They are primarily concerned with the righteousness and goodness of individuals' acts being a means to the righteousness and well-being of the whole society to which they belong (Auda, 2010). They cover the aspects of the objectives of Shariah, specifically those in the rules and regulations of the five protections mentioned above. In the context of Islamic financial institutions, it refers to the laws of financial transactions and principles.

\subsection{General Shariah Objectives of VBI:}

In the context of general objectives, VBI attempts to deliver the following goals that are targeted for the public interest in general.

\section{The Achievement of Justice:}

Generally, the achievement of justice in IBIs embraces two dimensions: macro and micro dimensions. In the macro dimension, the realization of a just economic system can be achieved through wealth distribution and circulation, efficiency in the utilization of resources and societal development (Laldin \& Furqani, 2013). In the context of VBI, justice is manifested through its underpinning thrusts such as 'Best Conduct' and 'Community Empowerment'. In the micro dimension, the thrust of 'Best conduct' emphasizes that the rights of stakeholders must be safeguarded via fair and transparent disclosure of all transactions and decisions made by the IBIs. Meanwhile, in the macro dimension, 'Community Empowerment' represents the full 
commitment of VBI towards the realization of social justice over a broader spectrum.

\section{Creating Values and Standards:}

The values and standards promoted in VBI is beyond Shariah Compliance, as it encompasses morals, ethics, good manners, and all sorts of values that bring goodness for societal well-being. These values and standards are observable and measurable and can be assessed through VBI's scorecard (BNM Strategy Paper, 2017).

\section{Enhancing Social Responsibility:}

VBI was created to maximize the roles of IBIs in discharging social responsibility and to find a balance between commercial and social aspects. Enhancing social responsibility could also lead to the achievement of social justice. For this reason, the concept of fard kifäyah has become one of the underlying principles of VBI. This principle has been set out in the thrust of 'Community Empowerment' whereby the focus of the thrust is to develop effective solutions for the communities who are facing difficulties and troubles in their financial needs (BNM Strategy paper, 2017).

\subsection{Specific Shariah objectives of VBI:}

Specific objectives of VBI do share the same objectives with the current Islamic financial activities. They have been described and discussed by many Shariah scholars. These objectives include the preservation of wealth through IBIs financial activities and transactions. Thus, it can be summarized that the specific objective of VBI is to achieve the following:

\section{Preservation of wealth through wealth circulation:}

The circulation of wealth is regarded as one of the great objectives of Shariah. Ibn 'Āshūr (2006) explains 'just wealth circulation' as a fair distribution of wealth among as many people in society. The idea of wealth going around refers to its transfer from one person to another, which is derived from the Qur'an, whereby Allah (SWT) says:

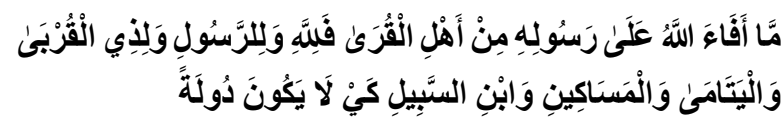

"And what Allah restored to His Messenger from the people of the towns - it is for Allah and for the
Messenger and for [his] near relatives and orphans and the (stranded) traveller - so that it will not be a perpetual distribution among the rich from among you" (AlQur'ān, 59:7).

Lahsasna (2013) further elucidates that there are at least two tools for wealth circulation: doing business and facilitating a financial transaction. By implementing VBI, it is hoped that it will assist IBIs to achieve the objective of preservation of wealth through wealth circulation by doing entrepreneurship or business that is in line with Shariah. On top of that, facilitating entrepreneurial activities as promoted in VBI is one of the tools for wealth circulation in IBIs by providing holistic offerings such as financial and proactive support.

\section{Preservation of wealth through wealth distribution:}

Wealth distribution refers to the proper way of placing wealth based on the rules and principles of Shariah. It is also a part of demonstrating the concept of sharing the wealth with others based on the assumption that a person does not have absolute authority on his wealth as the ultimate ownership of wealth belongs to Allah (SWT) (Lahsasna, 2013). Ibn 'Āshūr outlined several measures for the preservation of wealth such as prescribing financial measures in terms of collecting zakah to maintain a balanced society, promoting and rewarding charitable acts such as waqf, hibah, hadiyyah, and wașiyyah (Dusuki \& Bouheraoua, 2011).

VBI's 'Community Empowerment' thrust explains that the objective of wealth distribution can be attained through development, funding, and giving solutions for the issues faced by communities, such as the integration of waqf and sadaqah within the Islamic financial transactions. There are few indicators to measure the proper implementation of this thrust in IBIs. These indicators include number of communitybased services, products, projects, as well as the number of people that benefited from the communitybased activities, and the social impact (BNM Strategy Paper, 2017).

\section{Preservation of wealth through the protection of ownership}

In order to achieve the purpose of protecting ownership, any contracts relating to various kinds of deals have 
been instituted in IBIs to regulate the transfer of financial rights. All those contracts have been considered as binding because of the formulae; that is, the statements indicating the mutual consent of contracting parties (Dusuki \& Bouheraoua, 2011). 'Best conduct' represents the preservation of wealth through protection of ownership because the rights of stakeholders are safeguarded through transparent disclosure for all transactions and decisions by the IBIs.

\subsection{VBI and the Achievement of Public Interest (Maṣlaḥah)}

Public interest (Mașlaḥah) as explained in the preceding discussion, is divided into three categories based on its level of priority. This section elaborates all aspects of Mașlahah that can be achieved through VBI based on the following three levels of priority.

\section{The Essentials (Darūriyyāt)}

VBI has strongly emphasized the preservation of wealth through various tools and strategies as part of its cause of establishment. This means that VBI somehow becomes an essential driving force towards the realization of the preservation of wealth, which falls under the category of darüriyyāt. For this reason, it is the role of the managers of IBIs to ensure the preservation of wealth by protecting the rights and needs of their stakeholders as well as society. By ensuring proper implementation of VBI in IBIs, it will realize the objective of preservation of wealth.

\section{The Needs (Häjiyyät)}

As explained in the preceding discussion, this category of maslahah refers to the needs of society to achieve certain interests in order to ensure the optimal functioning of the lives of the people in society. Although overlooking this category will not cause mass destruction, it will undoubtedly create difficulties, and the lives of the people will become cumbersome.

In the context of VBI, this category of maslahah can be considered as manifesting the thrust of 'Good Self-Governance'. In this sense, the responsibility of IBIs is extended by ensuring that any decision made by an IBI will impact not only on its shareholders, but also the extended stakeholders, including the customers and investors (BNM Strategy Paper, 2017). For example, it is the responsibility of the IBIs to establish an effective and convenient platform - managed by a third party for the stakeholders to provide feedback or report their complaints (BNM Strategy Paper, 2017). Besides that, the incorporation of a culture of self-discipline that is based on the principle of Ihsān may help IBIs to achieve high accountability and integrity. In this instance, IBIs must provide an open channel that enables unceasing consultation with employees, and focuses on discussing ideas and concerns to improve the internal management of the institution (BNM Strategy Paper, 2017). Concerning this category of mașlahah, IBIs may have undergone certain difficulties due to a lack of participation from other stakeholders in their process of decision making, as there are limited platforms for other stakeholders to voice out their opinions and complaints.

\section{The Embellishments (Taḥsiniyyāt)}

Discharging social responsibilities by the IBIs is part of the embellishments. This can also be achieved by implementing VBI in IBIs under 'Community Empowerment'. The integration of waqf and sadaqah within Islamic financial transactions is one of the initiatives for the improvement of social responsibility awareness in IBIs. Therefore, it is imperative for the managers of IBIs in particular to understand this category of maslahah as they are the people who are responsible in the process of decision making, and this will help to ensure proper implementation of VBI in IBIs.

\section{Conclusion}

In conclusion, VBI is an intermediary that functions to deliver the intended outcomes of Shariah. These outcomes will be implemented through various strategies and practices. There are at least five Shariah principles that underlie the VBI's underpinning thrust: principles of Ihsān, principles of consultation, social obligation, and Shariah rules and regulations. These principles are genuinely derived from the Qur'ān, Sunnah, and other reliable sources of Shariah. Besides that, the establishment of VBI is expected to enable greater achievement of the Shariah objectives. Pertaining to the general objectives of Shariah, VBI is expected to deliver justice, establish values and standards, and enhance social responsibility. 
Meanwhile, in the perspective of specific Shariah objectives, VBI is aimed to implement the objectives of preservation of wealth through wealth distribution and circulation and protection of ownership. The achievement of VBI towards public interest could be observed in the order of priority of the different categories of Mașlahah. The researchers believe that the preservation of wealth, as one of the intended outcomes of the Shariah in VBI, falls under the category of darūriyyāt. Meanwhile, the thrust of 'Best Conduct' represents the manifestation of hajjiyyät and the thrust of 'Community Empowerment' can be categorized as tahsiniyyāt. Nonetheless, further research can be done by discussing another perspective of Maqāṣid al-Sharī'ah in VBI, especially due to finding a relationship between five aspects of protection as introduced by the Shariah scholars. The discussion on Maqāsid in this study is limited to the aspect of wealth preservation. Thus, a possible empirical study can be held in future researches by focusing on the stakeholders' perception of VBI.

\section{References}

Abdullah, A. (2017, July-August). Value-based Intermediation (VBI): the next big shift in Islamic Financial Landscape in Malaysia. Bulletin on Islam and contemporary issues, p.9.

Al-Fasi, 'Alal. 2014. Maqasid al-Syariah wa Makarimuha. Qaherah: Dar al-Kalimah.

Al-Ghazali, al-Mustasfa min 'Ilm al-Usul (Cairo: al-Maktabah alTijariyyah, 1973), 1, 139-140.

Asutay, M. and Harningtyas, A.F. (2015) "Developing Maqasid alShar'ah index to evaluate social performance of Islamic banks: a conceptual and empirical attempt, International Journal of Islamic economics and Finance studies., 1 (1). pp. 5-64.

Auda, Jasser. 2010. Maqasid al-Shariah As Philosophy of Islamic Law a System Approach. Petaling Jaya: Islamic Book Trust.

Bank Negara Malaysia. (2017). The Financial Stability and Payment Systems Report 2017, 1-140. Retrieved from www.bnm.gov.my

Bank Negara Malaysia. (2017). Value-based intermediation: Strengthening the roles and impact of Islamic finance, (July), 34.

Dusuki, A. W., \& Bouheraoua, S. (2011). The Framework of Maqasid Al-Shariah and Its Implication for Islamic Finance. ISRA Research Paper (2). pp. 1-49.

Ibn Ashur, M. A. (2006). Treatise on Maqasid al-Shari'ah. trans Mohamed El-Tahir El-Mesawi. Herdon: International Institute of Islamic Thought.

International Shariah Research Academy for Islamic Finance. (2011) Islamic Financial System Principles and Operations. Kuala Lumpur: ISRA.

Laldin, M.A, \& Furqani, H. (2013). Developing Islamic finance in the framework of maqasid al-Shari'ah: Understanding the ends (maqasid) and the means (wasa'il). International Journal of Islamic and Middle Eastern Finance and
Management,

$6(4)$ https://doi.org/10.1108/IMEFM-05-2013-0057

Laldin, M. A., \& Furqani, H. (2013). The Foundations of Islamic Finance and The Maqasid al-Shariah. Journal of Islamic Finance, 2(1), 31-37. (International Shariah Research Academy for Islamic Finance, 2011)

Lasasna, Ahcene. 2013. Maqasid al-Shariah in Islamic Finance. Kuala Lumpur: IBFIM.

Lewis, M. K. (2006). Accountability and Islam. Fourth International Conference on Accounting and Finance in Transition, 1-16.

Mahinar, N., \& Bakar, A. B. U. (2017). How Does Values-Based Banking Counter Unfair Terms in Consumer Contracts and Notices in Islamic Banks in Malaysia?. Proceeding of the 4th International Conference on Management and Muamalah (ICoMM 2017), 2017(ICoMM), 1-14.

Sahih al-Bukhari (1997). The translation of the meaning of Sahih alBukhari: Arabic-English. Riyadh: Dar as-Salam Publications.

Sahih International. Retrieved from The Noble of Quran: https://quran.com/ 